\title{
Early incidence of occupational asthma among young bakers, pastry-makers and hairdressers: design of a retrospective cohort study
}

\author{
Thomas Rémen*1,2, Vincent Coevoet1,2, Dovi-Stéphanie Acouetey1,2, Jean-Louis Guéant1,2, Rosa-Maria Guéant- \\ Rodriguez ${ }^{1,2}$, Christophe Paris 1,2 and Denis Zmirou-Navier1,2,3
}

\begin{abstract}
Background: Occupational exposures are thought to be responsible for 10-15\% of new-onset asthma cases in adults, with disparities across sectors. Because most of the data are derived from registries and cross-sectional studies, little is known about incidence of occupational asthma (OA) during the first years after inception of exposure. This paper describes the design of a study that focuses on this early asthma onset period among young workers in the bakery, pastry making and hairdressing sectors in order to assess early incidence of $\mathrm{OA}$ in these "at risk" occupations according to exposure duration, and to identify risk factors of OA incidence.

Methods/Design: The study population is composed of subjects who graduated between 2001 and 2006 in these sectors where they experience exposure to organic or inorganic allergenic or irritant compounds (with an objective of 150 subjects by year) and 250 young workers with no specific occupational exposure. A phone interview focusing on respiratory and 'Ear-Nose-Throat' (ENT) work-related symptoms screen subjects considered as "possibly OA cases". Subjects are invited to participate in a medical visit to complete clinical and lung function investigations, including fractional exhaled nitric oxide ( $\mathrm{FE}_{\mathrm{NO}}$ ) and carbon monoxide (CO) measurements, and to collect blood samples for lgE (Immunoglobulin E) measurements (total IgE and IgE for work-related and common allergens). Markers of oxidative stress and genetic polymorphisms exploration are also assessed. A random sample of 200 "non-cases" (controls) is also visited, following a nested case-control design.

Discussion: This study may allow to describ a latent period between inception of exposure and the rise of the prevalence of asthma symptoms, an information that would be useful for the prevention of OA. Such a time frame would be suited for conducting screening campaigns of this emergent asthma at a stage when occupational hygiene measures and adapted therapeutic interventions might be effective.
\end{abstract}

Trial registration: Clinical trial registration number is NCT01096537.

\section{Background}

The association between asthma and occupation is recognized since Antiquity [1] but our understanding of the pathophysiological mechanisms that are involved is still scanty. Definition of occupational asthma (OA) has been evolved along time. Recently, Bernstein [2] has described $\mathrm{OA}$ as " a disease characterized by variable airflow limitation and/or airway hyperresponsiveness due to causes and

\footnotetext{
* Correspondence: thomas.remen@nancy.inserm.fr

1 Institut National de la santé et de la Recherche Médicale U 954, School of Medicine, Nancy, France

Full list of author information is available at the end of the article
}

conditions attributable to a particular occupational environment and not to stimuli encountered outside the workplace [...]". This definition excludes "aggravated asthma", a pre-existent asthma which is exacerbated by working conditions.

Two forms of OA have been described: (i) the Reactive Airways Dysfunction Syndrome (RADS), which may be induced by acute inhalation of irritant substances; and (ii) the immunological type whose latency period after exposure is variable. RADS (which represents $5.5 \%$ to $9.5 \%$ of $\mathrm{OA}$ cases [3,4]) is a non-immunologic form of OA described by Brooks [5] as a persistent asthma syndrome 
following exposure to high levels of irritants, typically as a result of an accident occurring in the workplace or of a situation with poor ventilation and limited air exchange. The most frequent form of $\mathrm{OA}$ is the immunological form and arises after a latency period during which sensitization is acquired. The case of exposure to high molecular weight (HMW) agents (proteins $>5000$ daltons) differs from that implicating low molecular weight (LMW) agents (chemical products $<5000$ daltons), on account of their characteristics and the mechanisms that will eventually end up in OA.

Among HMW agents associated with OA, one can find several families of agents as, for example, animal-derived antigens, flour or pollen [6]. OA caused by exposure to HMW agents arises from mechanisms bounded to the production of IgE specific antibodies. This form of OA does not differ from non-occupational asthma associated with common pneumallergens in the environment [7]. In this category, bakers' asthma represents the first cause of $\mathrm{OA}$ in France [8] and one of the most current aetiology in countries of Western Europe [9-11]. Despite improvements in the implementation of occupational prevention measures, it affects an important proportion of workers in the bakery or pastry sectors. During the last twenty years, several authors have studied OA incidence among bakers with different methodologies, yielding incidence rates ranging from 0.334 to 2.46 cases per 1.000 personyears [3,9-17]. Three categories of agents are implicated: (i) flour (wheat, rye...) which is the main cause of baker's allergy, (ii) flour contaminants (storage mite, moulds,...) and (iii) substances added during bread making process $(\alpha$-amylase, baker's yeast, soy lecithin,...). Their relative importance depends on flour characteristics, stocking conditions and exposure intensity [18].

Diisocyanates and their arrangement, chemical products or products used in health field are some examples of the different families of LMW agents known to date as possibly implicated in OA [6]. As opposed to HMW agents, the mechanisms involved are still discussed. Some LMW substances are able to induce OA through an IgEdependant mechanism in a small proportion of persons. Among these substances are anhydrids (trimellitic and phtalic), diisocyanates, nickel and plicatic acid [18]. For others LMW substances, the physiopathology is more complex. Several characteristics of the condition suggest an immuno-allergic mechanism: the latency period between inception of exposure and occurrence of symptoms, or individual susceptibility. However, among affected subjects, IgE specific antibodies have not brought light for this category of LMW substances [19]. Hairdressing is one of the occupational sectors that is the most concerned by OA implicating exposure to LMW agents. In France, hairdressers represent the third cate- gory of workers with the highest risk of occupational asthma, following bakers/pastry makers and car painters, and the first category among females [3]. However, data about $\mathrm{OA}$ incidence are few for hairdressers $[3,20]$. In a retrospective Swedish nationwide study, Albin finds a higher asthma incidence during active years as a hairdresser (3.9 per 1.000 person-years) compared with the referents - women randomly selected from the general population (3.1 per 1.000 person-years; incidence rate ratio $(\mathrm{IRR})=1.2[95 \%$ confidence interval 1.0-1.6]) [21] While the incidence among hairdressers is smaller than in the bakery sector, several authors, as Ameille, observed an increasing trend: since the ONAP (Observatoire National des Asthmes Professionnels) was created in France in 1996, the proportion of OA in the hairdressing sector progressed from 5.5\% in 1996 to $8 \%$ in 1998 and $10 \%$ in 2000 [22], calling for a better surveillance in this occupation.

Whether among bakers or hairdressers, incidence figures are inclined to be underestimated. Studies based on workers at work are exposed to the "healthy worker effect", a selection bias. Also, owing to the fact that administrative procedures are complex or that some workers do not prefer to engage administrative procedures by fear of losing their job, official statistics are very imperfect. Moreover, they tend to weaken the OA frequency because they do not consider subclinical or mild forms of asthma. Finally, longitudinal studies are rare (especially concerning LMW agents) and the effect of exposure seniority has not been assessed. Nevertheless, a few cohort studies have been conducted in a variety of occupations and tend to demonstrate that "the most important risk for developing $O A$ is the level and duration of exposure to agents capable of causing $O A^{\prime \prime}$ [23]. Several studies demonstrated the existence of a dose-response relationship between exposure intensity and the prevalence of immunological sensitization to various occupational agents [13,24-28].

Now, while occupational exposure plays the key role, other factors, related to personal or more general characters, contribute also to the onset of the disease, among which are nutrients intake and genetic characteristics. From a genetic point of view, associations were described between $\mathrm{OA}$ and certain antigens of class 2 implicated in the presentation of antigens in the immunizing cells [2934] or some genotypes of the glutathione S-transferase and of the $\mathrm{N}$-acetyltransferase [35-37]. In a recent review, genetic factors that predispose asthma have been broken down into three broad categories: immune and inflammatory (12 genes), atopic (3 genes) and metabolic (one gene) [38]. Atopy is associated with an increased risk of developing an IgE mediated sensitization to HMW agents $[24-26,39,40]$. Occupational rhinitis is also associated 
with $\mathrm{OA}$ and rhinitis symptoms precede those of the asthma in $58 \%$ of the cases where HMW agents are implicated and in $25 \%$ of cases involving LMW [41].

In addition, the large increase in the prevalence of asthma observed in most developed countries [42] during the last decades has pointed toward environmental factors being responsible for part of this increase--particularly changes in diet, such as decreased consumption of fresh fruits and vegetables and unprocessed food [43-45]. Because of the components of airway constriction and inflammation involved in asthma, several nutritional factors that may act on muscle constriction or inflammatory response have been hypothesized to play a role on this disease. Romieu, in a literature review, suggests opposite associations between antioxidant vitamins intake (particularly vitamin $C$ and, to a lesser extent, vitamin E), omega-3 fatty acids or consumption of fresh fruit, and obstructive lung disease [46]. Our attention will also focus on the metabolism of folates, an area (which could play a role in asthma) that remains poorly explored to date. Most studies concerning methyl donors show their involvement in many inflammatory disorders (cardiovascular, neurodegenerative, autoimmune diseases...) $[47,48]$, and some studies have suggested their involvement in the development of atopy. For them, a dietary deficiency of methionine, folate and other B vitamins are associated with a high risk of atopy [49].

\section{Methods/Design}

The ABCD (french acronym for early asthma in bakery and hairdressing sectors) study aims to assess early incidence of OA among young workers according to their sector of activity and exposure duration, and to identify risk factors of OA.

\section{Study population}

This study is a retrospective follow-up with a nested casecontrol facet. Regarding the cohort study, the exposed population is composed of all bakers, pastry-makers and hairdressers who graduated between 2001 and 2006 from nine vocational schools in Lorraine, North-Eastern France, while the "non-exposed" group comprises all subjects who graduated in 2001 in the sale or the food sectors (butcher, pork butcher, caterer, cook job,...) from the same vocational schools. All those complying with these criteria are contacted by phone to complete a short screening questionnaire to ascertain OA symptoms. All subjects defined as "possibly with OA", based on the answers to this questionnaire (see further), and a matched sample of "non cases" (frequency matching criteria: year of graduation, vocational school and occupational sector) are proposed to be visited to perform a medical examination, spirometry and other tests which are detailed further. The research program is authorized by the Nancy University Hospital ethics committee and written consents are obtained from the young workers themselves.

\section{Sample size}

The calculated sample size aims at answering the two following objectives: (1) to show evidence of an increased incidence during the first years of occupational exercise among young bakers, pastry-makers and hairdressers as compared with young workers without specific occupational exposure; this objective will be pursued with the retrospective cohort study, and (2) to identify some risk factors, including genetic polymorphisms, of this increased incidence, through the nested case-control study. The estimated sample size for the retrospective cohort study should have the power to show a difference in OA incidence between young workers (bakers, pastrymakers and hairdressers) with high seniority (about seven years) and young workers with a low seniority (two years or less). A difference in cumulative incidence of $6 \%$ between these two groups (from 1 to $7 \%$ ) should be demonstrated with a sample of 150 subjects by year, with a power of $80 \%$ and an $\alpha$-risk of $5 \%$ (two-tailed test). Further, a sample of 250 young workers with no specific occupational exposure should be used to demonstrate a significant difference of OA incidence after about seven years of activity between bakers, pastry-makers and hairdressers and this "non-exposed" group (expected incidence $3 \%, \alpha=5 \%$ and $1-\beta=75 \%$ ). The total sample to be investigated in the telephone interview is therefore 1150 young workers. It is expected to provide about 40 possible cases of OA (see further the operational definition of $\mathrm{OA}$ in this study). For this number, the nested case-control study would need about 200 controls in order to have the power $(1-\beta=80 \%)$ to detect relevant single nucleotide polymorphisms (SNP) associated with differences in allele frequencies between cases and controls of about 16 to $24 \%$ across a set of reasonable allele frequencies among controls (from 5 to $35 \%$; two-tailed test, $\alpha=5 \%, 1-\beta=$ $80 \%$ ). Similar comparisons can be made for other risk factors with differences in prevalence of this order of magnitude.

\section{Recruitment procedure}

Nine vocational training centres in Lorraine participate in the study. They identified from their archives all apprentices who graduated in bakery, pastry, hairstyle, sale or food sectors between 2001 and 2006, along with the apprentices' or parents' addresses and phone numbers during their last training year. Because of the mobility of the young workers during the first years of their occupational activity (departure from family home in particular), a preliminary step was organized. A postal mail was sent to all parents, comprising an explanatory letter, an infor- 
mation sheet on OA and a reply coupon to be completed and returned with the current address and phone number(s) of the young worker. Up to three reminders (two by mail then one by phone) were sent to maximize the response rate.

A medical questionnaire is also administrated by phone to each worker for whom we have a phone number. Participants are subjects who met the following inclusion criteria: (i) no history of asthma before apprenticeship, and, (ii) for "non-exposed" subjects, not to have worked, before or after apprenticeship, in an occupation at risk of OA.

\section{$O A$ diagnosis and $O A$ timing}

The OA diagnosis is made in two times: (i) diagnosing asthma, and (ii) highlighting a temporal relation of symptoms with work activities. The decision tree for defining
$\mathrm{OA}$ is presented in figure 1 . The tests that are undertaken during the medical visit at home to confirm a case of OA will be presented further.

For subjects who present work-related respiratory symptoms and for whom a diagnosis of OA or probable $\mathrm{OA}$ is evoked or confirmed by a doctor, the date retained for this diagnosis corresponds to the first occurrence of the respiratory symptoms. On the other hand, for subjects considered as asthmatics (infra-clinical form) because of their results to the tests performed during the visit and their occupational exposure and who present only work-related ENT symptoms, the corresponding date is that of the medical visit.

\section{Initial telephone screening questionnaire}

During the first step of the study, nurses trained for this study administer a short standardized questionnaire by

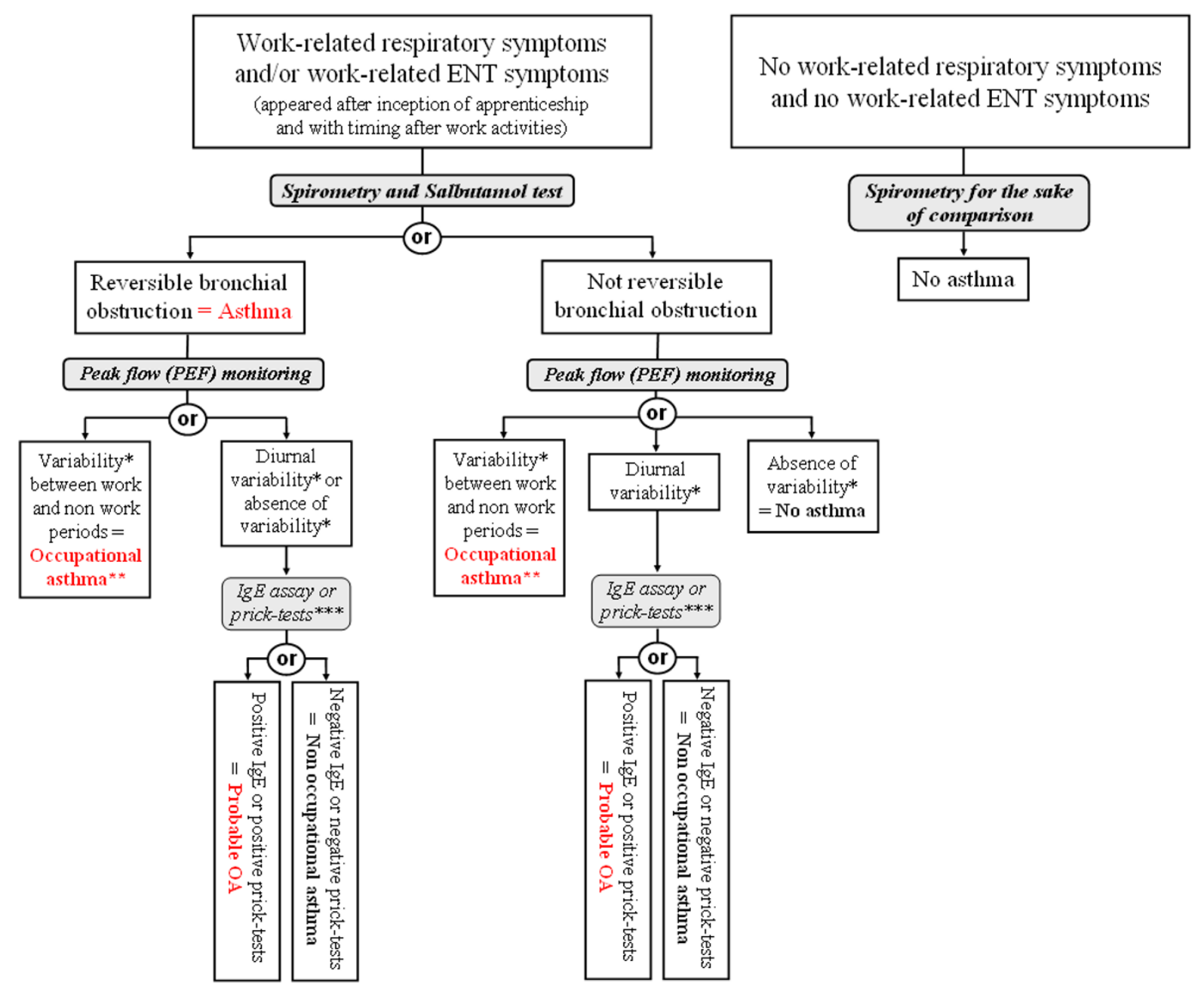

Figure 1 Decision tree for the definition of occupational asthma. * Variability is defined by the Oasys-2 score as deterioration during a work period or improvement during a period away from work of at least $20 \%$. ${ }^{* *}$ When only ENT symptoms are present, the diagnosis of infraclinic OA is more appropriate. ${ }^{* *}$ IgE Assay (bakers and pastry makers) and prick-tests (hairdressers) were realized for specific occupational allergens. 
phone concerning exposure duration, respiratory, ENT, skin symptoms and smoking status. This phone interview aims to screen subjects who are likely to exhibit OA and allows classifying them into three categories: "workrelated respiratory (+/- ENT) symptoms", "only workrelated ENT symptoms" and "absence of work-related symptoms".

Work-related respiratory symptoms are considered present if three conditions are combined: (a) presence of a diagnosed asthma or at least one of the respiratory symptoms (wheezing, breathlessness, chest tightness, cough and sputum) during the last 12 months. [If the person has left his/her activity or was found to take asthma medication, the 12 months period was defined before quitting and/or starting medication intake] (b) the symptoms should have appeared after inception of apprenticeship; and (c) symptoms are present during the working days and improve or disappear during week-ends or holidays.

Work-related ENT symptoms are considered present if three conditions are combined: (a) presence of at least one major symptom of rhinitis (nasal obstruction, runny nose) during the last 12 months (or during the 12 months prior to quitting the activity if the subject has switched to another occupation than the one for which he/she had been trained); (b) the symptoms should have appeared after inception of apprenticeship or, for atopic subjects, ENT symptoms should have been aggravated at work; and (c) symptoms are present during the working days. [Amendment or disappearance of these symptoms during week-ends or holidays is not considered, not to overlook chronic rhinitis with an occupational origin.]

We define all subjects that pertain to one of these two first categories as "possibly OA case". All others are defined as "non cases".

Information concerning exposure (duration of apprenticeship, diplomas obtained, duration of occupational exposure) and smoking status are also collected. Current smokers are defined as subjects who reported smoking on average at least one cigarette a day for at least one year and past smokers are defined as subjects who reported past smoking but who do not smoke any more.

If participation to this interview is declined, we try to retrieve basic data during the phone exchange: information about study inclusion criteria, reasons if he/she has left his/her training sector if relevant, and whether the subject had asthma symptoms or treatment.

\section{Medical visits}

All subjects considered as "possibly OA case" are offered a visit. Also, a random sample of two hundreds "non cases" are selected and offered a medical visit that met two criteria: (i) to be representative of all the subjects who graduated between 2001 and 2006 as to the training sector (bakery and pastry, hairstyle or others), the year of graduation (2001-2002; 2003-2004 or 2005-2006) and the vocational school (graduated in the Moselle department with 4 schools - or others) and (ii) to be representative of all those who complete the phone questionnaire concerning the prevalence of symptoms (work-related respiratory symptoms, work-related ENT symptoms and others).

Prior to the visit (about fifteen days before), a letter is sent to each volunteer, including an explanatory letter and an information sheet on OA, consent forms (to be completed and returned) and a food consumption questionnaire (to be completed and brought back during the visit).

Two persons, including a physician, participate to each visit (TR and DSA or TR and an intern). The duration of each visit is approximately one hour and a half. The examinations take place in this following order:

\section{1-Clinical examination and questionnaire}

The clinical history is evaluated with a standardized questionnaire with a view to check and complement the data collected during the phone screening questionnaire: personal and family antecedents, exploration of symptoms associated with a variety of exposures (environmental tobacco smoke, air pollution, dust, ...), past and present smoking habits, details on respiratory, ENT and skin symptoms. Medical antecedents are looked for (respiratory and ENT diseases, allergic conditions), and pathologies which contraindicate the bronchodilator reversibility test (hyperthyroidism, cardiac conditions). More detailed data on smoking are collected: number of cigarettes smoked, duration of smoking.

A clinical examination, including pulmonary auscultation centred on pulmonary, ENT, ophthalmologic and skin symptoms is then conducted, searching for sibilants, signs of conjunctival irritation, nasal or bronchial obstruction or atopic diseases. Weight, size and blood pressure are recorded.

\section{...and verification of the food consumption questionnaire}

Due to the importance of dietary factors in aetiopathogenic hypotheses of asthma, diet is assessed by a food frequency questionnaire (SUVIMAX 2: http:// clinicaltrials.gov/ct2/show/NCT01096537). It is sent by mail to all subjects who accepted the medical examination and is collected during the visit and verified. It will in particular be used to qualitatively evaluate dietary imbalance of nutritional factors of interest: vitamin B (folates, B12, B6, B2), polyphenols, carotenoids, vitamins E and C, omega-3 polyunsaturated fatty acids (PUFA).

\section{2-Occupational exposure questionnaire}

To quantify occupational exposure, a questionnaire is completed during the visit. Three distinct questionnaires are used: one for bakers and pastry-makers, one for hairdressers and the other for the referent population. The two former questionnaires have been devised after an 
exposure study among apprentices in their workplace $[50,51]$ and comprise different sections: occupational history, work tasks, occupational environment and safety devices; the last section allows identifying allergens that may be encountered in the workplace. For "non-exposed" workers, the questionnaire only comprises the first and the last section.

\section{3- Exhaled NO and $\mathrm{CO}$ measurements}

To complete the smoking status, $\mathrm{CO}$ is measured by a portable analyzer (Micro $\mathrm{CO}^{\circ}$ analyser, Micro Medical, United Kingdom) that provides values after a single expiration.

Because $\mathrm{FE}_{\mathrm{NO}}$ has been shown by our team as an early marker of airways inflammation among bakery and hairdressing apprentice [52], the Fractional Exhaled Nitric Oxide $\left(\mathrm{FE}_{\mathrm{NO}}\right)$ is measured by a portable analyzer (NioxMino analyzer, Aerocrine, Sweden). All participants will undergo the measurement of $\mathrm{FE}_{\mathrm{NO}}$ using the NIOX analyzer at a mouth flow rate of $50 \mathrm{~mL} / \mathrm{s}$ and a pressure of 10 $\mathrm{cm} \mathrm{H}_{2} \mathrm{O}$. A single measurement is then undertaken immediately afterward using the portable MINO device with identical mouth flow rate and pressure settings.

\section{4-Spirometry}

After $\mathrm{CO}$ and $\mathrm{FE}_{\mathrm{NO}}$ measurements, spirometry is performed in the standing position using Spirolab II (RDSM Co., Italy). Forced vital capacity (FVC), forced expiratory volume in one second (FEV1) and peak expiratory flow rate at various percentages of vital capacity (V'max) are obtained during forced expiration from total lung capacity. At least three forced expirations satisfying the American Thoracic Society (ATS) criteria [53] are performed. The highest values for FVC and FEV1 are used for analysis. Results are expressed as percentage of predicted values using the equations recommended by the European Respiratory Society (ERS) [54]. The ATS/ERS norms are used for results interpretation [55]. For all subjects with work-related symptoms, a reversibility test is realised (inhalation of four separate doses of $100 \mathrm{mg}$ of salbutamol). Known hypersensitivity to one of the ingredients of Salbutamol and a contraindication to the use of this drug (heart failure, hypertension, diabetes, etc.) don't allow the realization of this test. Reversibility is defined by an increase of $\mathrm{FEV}_{1}$ by at least $12 \%$ and at least $200 \mathrm{ml}$ compared with baseline during a single test session $[55,56]$.

\section{5-Blood sampling}

Blood samples are taken to determine total and specific IgE by the Phadia method (wheat flour, $\alpha$-amylase and baker's yeast, quaternary ammoniums, persulfates, and also common allergens to evaluate the atopic status); circulating concentrations of vitamin B (folate, B12), carotenoids, vitamin E, omega 3 fatty acids; inflammation and lipid parameters [57] (triglycerides, phospholipids, total cholesterol, HDL-cholesterol, C reactive protein, TNF $\alpha$ and IL1 $\beta$ ); metabolic markers (homocysteine) [58]; and markers of oxidative stress (erythrocyte SOD1, glutathione peroxidase, glutathione reductase, 4-hydroxynonenal, malondialdehyde). Two 5 to $7 \mathrm{ml}$ EDTA tubes and one $5 \mathrm{ml}$ tube of serum are collected for this purpose.

In addition, due to their potential role in our pathophysiological model, a number of genetic variants have been preselected from a search on the SNP NCBI database and Hapmap: (i) variants with a phenotypic expression and/or associated with functional alterations related to asthma and (ii) variants related to asthma and with an allele frequency $>10 \%$. These determinants are studied on the genotyping platform Illumina BeadXpress of Inserm U954, which allows to genotype 300 SNPs on a macro-array. In addition, we also look for polymorphisms that have already been studied in the asthma and bronchial inflammation literature: TNF $\alpha$ [59], IL-1 cluster (IL1 $\alpha$, IL1 $\beta$, and IL1RN) [60,61]. Regarding bioavailability and metabolism of n-3 fatty acids and polyphenols, we study the polymorphisms of gene involved in blood and cellular transport, including Apo AIV, APO E, CETP, HL480, I- and L-FABP, LPL, MTP, PLTP, ABC, SR-B1, $\mathrm{ABCA} 1$ and 3, and CD36. And finally, concerning metabolism of homocysteine, we study a selection of 380 gene variants involved in the cellular metabolism of folate and cycle of methionine and in the absorption and transport of folate and vitamin B12, including variants from MTHFR, MTR, MTRR, TCN2, GIF, RFC and COMTs.

\section{6- Peak-Flow monitoring}

All subjects who report work-related respiratory and/or ENT symptoms are asked to monitor peak expiratory flow rate (PEFR) for three weeks [62]. They are given a peak-flow meter (Asma-1', Vitalograph, Ennis, Ireland), a results sheet, and instructions on how to use the device. They have to measure their PEFR four times a day: two on the workplace (the first one 2-3 hours after the beginning and the second one at the end of the work shift), and two out of work (one before going to work and the other at bedtime) $[63,64]$. For each measurement, the best value of three attempts is kept. PEFR variability is calculated between values at work and out of work, for each day, during the three weeks of the follow-up. An increase of PEFR variability is considered to be clinically relevant when the relative frequency of days with a $20 \%$ variation of PEFR differs by at least $10 \%$ between days at work and days off work. The computer program Oasys-2 is used to plot and interpret serial PEFR readings: curves connecting the points are used to construct curves of the timecourse of PEFR. The Oasys work effect index gives a score between 1 and 4 (or zero if nothing to score). Scores above 2.5 have $94 \%$ specificity for occupational asthma and $75 \%$ sensitivity when using independent methods of diagnosis, so a negative score cannot be used to exclude occupational asthma [65]. 


\section{7- Skin prick-tests (optional)}

The hairdressers, whom diagnosis of OA is evoked but not confirmed by the peak-flow monitoring, will be directed to a specialized structure to perform skin pricktests with occupational allergens.

\section{Data capture and analysis}

Data are entered in a database by optical scanning device. Additional visual control of these entries is realised by a technician. The analysis comprises several steps. After description of the whole study population and of subjects who had the medical visits, the overall OA incidence will be compared across the job sectors. Among bakers and pastry makers or hairdressers, OA incidence will be computed according to seniority. Finally, a nested case-control logistic regression analysis will be used to identify risk factors of OA (nutritional, genetic polymorphisms or others factors such as tobacco smoking).

\section{Discussion}

\section{Study design and study population}

This study includes six groups of subjects of increasing age and duration of exposure since termination of apprenticeship across different jobs. Exposure duration has been evoked as a determinant of asthma in occupations at risk $[23,66]$. This study strives to quantify this association according to exposure duration to allergens and irritants. Some subjects might quit soon, because of airways impairment and allergies, a phenomenon that underlines the relevance of studying the early times since inception of exposure $[67,68]$.

Not to require an authorization from employers, medical visits take place at home, before or after the work shift, during week-ends or holidays. This setting, where subjects are not seen in their exposure situation, might reduce the capacity of the study to identify bronchial obstruction induced by exposure to occupational allergens and/or irritants. This problem is also encountered for the interpretation of $\mathrm{FE}_{\mathrm{NO}}$ measurement, which might underestimate the true prevalence of bronchial inflammation. For this reason, peak expiratory flow rate (PEFR) surveillance is realized for all participants presenting evocative symptoms, irrespective of other tests.

This study includes successive cohorts of increasing time since engaging in the occupations of interest. In each cohort the data that are collected combine crosssectional information (clinical and biological data collected during the medical visit), and historical information (reconstruction of the clinical history and of the exposure at work in a retrospective manner). This methodology might suffer from a memorization bias. However, the young age of our population is likely to reduce this limitation. We define the date of OA diagnosis as the first occurrence of respiratory symptoms at work; it is the date of the visit, when dealing with subjects with no respiratory symptom. This is done not to overestimate the latency period, i.e. the time between the start of occupational exposure and occurrence of OA, a bias that affects a majority of the studies which date asthma onset according to when it was diagnosed.

Subjects who, after completion of their apprenticeship, found a job out of the Lorraine region could not be seen, because the distance precluded visiting them. There is no reason why this subgroup (which represents approximately 10 per cent of subjects considered as "at risk") should exhibit an asthma incidence pattern different from that of their counterparts who set in the region. To avoid underestimation of $\mathrm{OA}$ incidence, the number of $\mathrm{OA}$ cases will be assessed in this subgroup using the data from visits.

For the "non-exposed" job categories, we have selected young workers who graduated in the same vocational schools in order to have similar socio-demographic profiles, thus reducing the influence of factors other than occupational. The selected jobs are from the sales or the food sectors, which represent a large number of occupations after apprenticeship in France.

\section{Relevance of the project}

In addition to the care given to the reconstruction of the occupational history of each subject since inception of apprenticeship, this study tackles a large number of determinants of OA in "at risk" occupations. The greatest prevalences are observed in France among bakers and pastry makers, but increasing number of cases was seen among women over the last years, in particular in hairdressers [3]. Bakery and, to a lesser degree, pastry making, entail exposure to high concentrations of flour dust and to fungal $\alpha$-amylase enzyme, which have sensitising properties. Bakers and pastry makers also experience peak and shortlasting exposures (minutes) [69,70] (Mounier-Geyssant E, Massin N, Paris C, Zmirou-Navier D: Longitudinal analysis of activities inducing peak exposures to flour dust among bakery and pastry apprentices, submitted). Albin et al. [21] showed a slightly, but not significantly, higher incidence of asthma in hairdressers that often perform hair bleaching treatments or use hair sprays compared with more infrequent users, and Akpinar-Elci et al. [71] found a higher risk of occupational asthma in high work intensity hairdressers. On the other hand, Iwatsubo et al were unable to describe a specific hairdressing activities related to the deterioration of lung function they found among hairdressing apprentices during a 3-year followup [72].

A relationship between diet and asthma has also been described. The "nutritional hypothesis" ascribes the increase in respiratory allergies to changes in dietary intake, principally of anti-oxidants and lipids [73,74]. 
Anti-oxidants and omega 3 PUFA may have beneficial effects on the incidence of asthma and on atopic diseases [73]. Since asthma in adults is associated with a low intake of fruits, nutritional anti-oxidants, vitamin $\mathrm{C}$, and magnesium, it has been suggested that the diet is a potentially modifiable risk factor for the development of asthma [75]. Several epidemiological studies demonstrated that dietary vitamin $\mathrm{C}$ intake or serum ascorbate is positively associated with ventilatory function in children and adults [76,77]. Positive effects have also been shown for dietary vitamin $\mathrm{E}$ on lung function [76-79] and possibly on asthma and atopy $[80,81]$. However, the effectiveness of asthma and respiratory allergies prevention through dietary supplementation is still debated [82].

This study will allow investigating a variety of gene known to be involved in disease and gene-gene interactions. No study has previously, to our knowledge, considered simultaneously the nutrigenetic, nutrigenomic and metabolic interactions regarding the association between genetic determinants and airways inflammation.

The interaction between occupational exposure and nutrition modulated by certain SNP of genes involved in the production of proinflammatory factors or in the metabolism of B group vitamins has not yet been studied and would therefore be an original aspect of this project. This might help elucidate, if any, differential incidences of early asthma in these high-risk occupations. Hence, in phase with a recent editorial call in the European respiratory Journal [83], this project is highly multidisciplinary, associating an occupational health perspective -as occupational asthma constitutes a serious health problem and a mechanistic perspective, with exploration of the metabolic processes involved in oxidative stress and immunological sensitization induced by occupational exposure, and of some of their genetic determinants.

\section{Asthma diagnosis}

The diagnosis of asthma is usually based on the presence of characteristic symptoms such as episodic breathlessness, wheezing, cough and chest tightness [84]. Now, the medical examination serves to exclude rather than to confirm the diagnosis of OA [85]. Measurement of lung function is also recommended. Because our study takes place in the field, bronchial challenge to metacholine, a test which is considered as the gold standard, is not practicable. Assessing whether an obstructive syndrome is reversible after bronchodilatator inhalation (here, Salbutamol) is an important step in the diagnosis of asthma. Hence, our definition of asthma is based on the presence of a reversible bronchial obstruction as described in the Global Initiative for Asthma [54]. Now, many asthmatic subjects may have normal or near-normal pulmonary function, especially at distance from exposure and during non exacerbation periods [86]. To account for this, we chose to perform peak-flow monitoring for all subjects who report work-related respiratory or ENT symptoms. A daily PEFR amplitude (measured as the highest daily value minus the lowest daily value) greater than $20 \%$ supports the diagnosis of asthma [54,87]. Several researchers have suggested that serial measurements of PEFR at the workplace and away from the workplace is an objective measure and an appropriate first step in establishing a causal relationship between work and lung function alteration, or asthma $[62,65,88]$. The Oasys quality critera for a serial peak flow record is defined as being of adequate quality if it lasts at least 2.5 weeks, with at least 4 readings per day and 3 consecutive workdays in each work period. In this setting, the sensitivity and specificity of adequate records were respectively $78.1 \%$ and $91.8 \%$, versus $63.6 \%$ and $83.3 \%$ for inadequate records [62]. While serial PEFRs have a number of advantages as a tool for diagnosing sensitizer-induced OA, they also have some limitations. They are effort dependent and require good cooperation from subjects being investigated. PEFRs may be incomplete or uninterpretable for a variety of reasons $[89,90]$. In case of doubt concerning the occupational character of the asthma, other examinations (IgE assays or Prick-tests) will be used for the diagnosis.

Some subjects had stopped to work in the sector they had been trained for. Excluding them might yield underestimation of the frequency of $\mathrm{OA}$ if some quit because they experienced untoward consequences of the exposures of interest. So, they remain in our study but only the symptoms during the 12 months prior to quitting are considered. However, for these subjects, serial measurements of PEFR cannot any more bring to light variability between measurements at the workplace in their initial job and away from the workplace. Only diurnal variability can be recorded. For such subjects who would present work-related respiratory symptoms (as defined in our study) associated with diurnal PEFR variability, dosage of specific IgE is used to assess the association between occupational exposure and symptoms. Positive cases are considered as "probable OA". This test is less relevant for hairdressers, in absence of a demonstrated underlying IgE mediated mechanism for persulphates [91]. Unfortunately, the University hospital requires that skin pricktests be done in a medical environment, thus precluding their realization in the study setting. Because of these different limitations, hairdressers can be invited to ask their general physician to realize skin prick tests (commons allergens, persulfates, latex, and sericine) and to report their results.

\section{Conclusions}

This study may allow describing a latent period between inception of exposure and the rise of the prevalence of asthma symptoms and to compare this time pattern 
according to the nature of exposure, an information that would be useful for the prevention of OA. Such a period would be suited to undertake screening campaigns of this emerging asthma at a stage when occupational hygiene measures and adapted therapeutic interventions, might be effective.

\section{Abbreviations}

OA: occupational asthma; ENT: Ear-Nose-Throat; $\mathrm{FE}_{\mathrm{N}}$ : fractional exhaled nitric oxide; CO: carbon oxide; IgE: immunoglobulin E; RADS: reactive airways dysfunction syndrome; HMW: high molecular weight; LMW: low molecular weight; IRR: incidence ratio rate; ONAP: observatoire national des asthmes professionnels; ABCD: asthme en boulangerie et coiffure débutant; SNP: single nucleotide polymorphism; PUFA: polyunsaturated fatty acids; FVC: forced vital capacity; $\mathrm{FEV}_{1}$ : forced expiratory volume in 1 second; $V^{\prime}$ max: maximal expiratory flows at various lung volumes; ATS: american thoracic society; ERS: european respiratory society; PEFR: peak expiratory flow rate.

\section{Competing interests}

The authors declare that they have no competing interests.

\section{Authors' contributions}

TR carried out the epidemiologic study, drafted the manuscript and participates in the medical visits with VC and DSA for data collection; he will perform the statistical analysis. TR, DS, JLG, RMG participated in the design of the protocol. CP and DZN designed the study and drafted the manuscript. All authors read and approved the final manuscript.

\section{Acknowledgements}

The authors are grateful to the young workers who volunteer in this study and to their family for the recruitment preliminary step. They thank the directors and the administrative personnel of the 9 vocational training centres of Lorraine of Bar-Le-Duc, Forbach, Gérardmer, Epinal, Laxou, Metz, Nancy, Epinal, Thionville.

This study is supported by the following institutions: AFSSET (Agence Française de Sécurité Sanitaire de l'Environnement et du Travail), PHRC (Programme Hospitalier de Recherche Clinique), Conseil régional de Lorraine, Conseil Général de Meurthe et Moselle, Communauté Urbaine du Grand Nancy. Thomas Remen and Dovi-Stéphanie Acouetey are recipients of a doctoral scholarship from General Council of Lorraine.

\section{Author Details}

1Institut National de la santé et de la Recherche Médicale U 954, School of Medicine, Nancy, France, 2University Medical School, Nancy, France and ${ }^{3}$ EHESP School of Public Health, Rennes, France

\section{Received: 1 April 2010 Accepted: 26 April 2010}

Published: 26 April 2010

\section{References}

1. Bernstein JA: Occupational asthma. 'My job is making me sick!'. Postgraduate medicine 1992, 92(3):109-112.

2. Bernstein I, Chan-Yeung M, Malo J, Bernstein D: Definition and classification of asthma. In Asthma in the Workplace Inc. MD. New York; 1993:1-4.

3. Ameille J, Pauli G, Calastreng-Crinquand A, Vervloet D, Iwatsubo Y, Popin E, Bayeux-Dunglas MC, Kopferschmitt-Kubler MC: Reported incidence of occupational asthma in France, 1996-99: the ONAP programme. Occupational and environmental medicine 2003, 60(2):136-141.

4. Rosenman KD, Reilly MJ, Kalinowski DJ: A state-based surveillance system for work-related asthma. Journal of occupational and environmental medicine/American College of Occupational and Environmental Medicine 1997, 39(5):415-425.

5. Brooks SM, Weiss MA, Bernstein IL: Reactive airways dysfunction syndrome (RADS). Persistent asthma syndrome after high level irritant exposures. Chest 1985, 88(3):376-384.

6. List of agents causing occupational asthma [http:// www.asthme.csst.ac.ca/document/Info Gen/AgenProf/Bernstein/ BernsteinAng.htm]
7. Malo IL, Chan-Yeung M: Occupational asthma. The Journal of allergy and clinical immunology 2001, 108(3):317-328.

8. Kopferschmitt-Kubler MC, Ameille J, Popin E, Calastreng-Crinquand A, Vervloet D, Bayeux-Dunglas MC, Pauli G: Occupational asthma in France: a 1-yr report of the observatoire National de Asthmes Professionnels project. Eur Respir J 2002, 19(1):84-89.

9. Karjalainen A, Kurppa K, Virtanen S, Keskinen $\mathrm{H}$, Nordman $\mathrm{H}$ : Incidence of occupational asthma by occupation and industry in Finland. American journal of industrial medicine 2000, 37(5):451-458

10. Meredith S: Reported incidence of occupational asthma in the United Kingdom, 1989-90. Journal of epidemiology and community health 1993, 47(6):459-463.

11. Toren K: Self reported rate of occupational asthma in Sweden 1990-2. Occupational and environmental medicine 1996, 53(11):757-761.

12. Bena A, D'Errico A, Mirabelli D: A system for the active surveillance of occupational bronchial asthma: the results of 2 years of activity of the PRiOR program. La Medicina del lavoro 1999, 90(4):556-571.

13. Brisman J, Jarvholm B, Lillienberg L: Exposure-response relations for self reported asthma and rhinitis in bakers. Occupational and environmental medicine 2000, 57(5):335-340.

14. Gannon PF, Burge PS: The SHIELD scheme in the West Midlands Region, United Kingdom. Midland Thoracic Society Research Group. British journal of industrial medicine 1993, 50(9):791-796.

15. Leira HL, Bratt U, Slastad S: Notified cases of occupational asthma in Norway: exposure and consequences for health and income. American journal of industrial medicine 2005, 48(5):359-364.

16. Meyer JD, Holt DL, Cherry NM, MCDonald JC: SWORD '98: surveillance of work-related and occupational respiratory disease in the UK. Occupational medicine (Oxford, England) 1999, 49(8):485-489.

17. Smith TA, Patton J: Health surveillance in milling, baking and other food manufacturing operations--five years' experience. Occupational medicine (Oxford, England) 1999, 49(3):147-153.

18. Bohadana A, Teculescu D: Asthme et rhinite d'origine professionnelle. INSERM; 2000:95.

19. Chan-Yeung M, Malo JL: Occupational asthma. The New England journal of medicine 1995, 333(2):107-112.

20. Leira HL: Occupational asthma in Norway. Tidsskr Nor Laegeforen 2008 , 128(23):2719-2721

21. Albin M, Rylander L, Mikoczy Z, Lillienberg L, Dahlman Hoglund A, Brisman J, Toren K, Meding B, Kronholm Diab K, Nielsen J: Incidence of asthma in female Swedish hairdressers. Occupational and environmental medicine 2002, 59(2):119-123.

22. Ameille J: Asthme professionnel: présentation du thème: incidence, étiologies, pronostic médical et social. Arch Mal Prof 2002, 63(34):306-307.

23. Newman Taylor A: Asthma and Work: The Colt Lecture, delivered at the Ninth International Symposium on Inhaled Particles, Cambridge, September 2001. The Annals of occupational hygiene 2002, 46(7):563-574

24. Cullinan P, Cook A, Nieuwenhuijsen MJ, Sandiford C, Tee RD, Venables KM, McDonald JC, Newman Taylor AJ: Allergen and dust exposure as determinants of work-related symptoms and sensitization in a cohort of flour-exposed workers; a case-control analysis. The Annals of occupational hygiene 2001, 45(2):97-103.

25. Cullinan P, Harris JM, Newman Taylor AJ, Hole AM, Jones M, Barnes F Jolliffe G: An outbreak of asthma in a modern detergent factory. Lancet 2000, 356(9245):1899-1900.

26. Gautrin D, Infante-Rivard C, Ghezzo H, Malo JL: Incidence and host determinants of probable occupational asthma in apprentices exposed to laboratory animals. American journal of respiratory and critical care medicine 2001, 163(4):899-904.

27. Merget R, Kulzer R, Dierkes-Globisch A, Breitstadt R, Gebler A, Kniffka A, Artelt S, Koenig HP, Alt F, Vormberg R, Baur X, Schultze-Weminghaus G: Exposure-effect relationship of platinum salt allergy in a catalyst production plant: conclusions from a 5-year prospective cohort study. The Journal of allergy and clinical immunology 2000, 105(2 Pt 1):364-370.

28. Nieuwenhuijsen MJ, Heederik D, Doekes G, Venables KM, Newman Taylor AJ: Exposure-response relations of alpha-amylase sensitisation in British bakeries and flour mills. Occupational and environmental medicine 1999, 56(3):197-201.

29. Beghe B, Padoan M, Moss CT, Barton SJ, Holloway JW, Holgate ST, Howell WM, Mapp CE: Lack of association of HLA class I genes and TNF alpha- 
308 polymorphism in toluene diisocyanate-induced asthma. Allergy 2004, 59(1):61-64

30. Horne C, Quintana PJ, Keown PA, Dimich-Ward H, Chan-Yeung M: Distribution of DRB1 and DQB1 HLA class II alleles in occupational asthma due to western red cedar. Eur Respir J 2000, 15(5):911-914.

31. Jeal H, Draper A, Jones M, Harris J, Welsh K, Taylor AN, Cullinan P: HLA associations with occupational sensitization to rat lipocalin allergens: a model for other animal allergies? The Journal of allergy and clinical immunology 2003, 111(4):795-799.

32. Jones MG, Nielsen J, Welch J, Harris J, Welinder H, Bensryd I, Skerfving S, Welsh K, Venables KM, Taylor AN: Association of HLA-DQ5 and HLA-DR with sensitization to organic acid anhydrides. Clin Exp Allergy 2004, 34(5):812-816.

33. Mapp CE, Beghe B, Balboni A, Zamorani G, Padoan M, Jovine L, Baricordi OR, Fabbri LM: Association between HLA genes and susceptibility to toluene diisocyanate-induced asthma. Clin Exp Allergy 2000, 30(5):651-656.

34. Rihs HP, Chen Z, Rueff F, Cremer R, Raulf-Heimsoth M, Baur X, MoneretVautrin DA, Bruning T: HLA-DQ8 and the HLA-DQ8-DR4 haplotype are positively associated with the hevein-specific lgE immune response in health care workers with latex allergy. The Journal of allergy and clinical immunology 2002, 110(3):507-514

35. Wikman H, Piirila P, Rosenberg C, Luukkonen R, Kaaria K, Nordman H, Norppa $\mathrm{H}$, Vainio H, Hirvonen A: N-Acetyltransferase genotypes as modifiers of diisocyanate exposure-associated asthma risk. Pharmacogenetics 2002, 12(3):227-233.

36. Piirila $\mathrm{P}$, Wikman $\mathrm{H}$, Luukkonen $\mathrm{R}$, Kaaria $\mathrm{K}$, Rosenberg $\mathrm{C}$, Nordman $\mathrm{H}$, Norppa H, Vainio H, Hirvonen A: Glutathione S-transferase genotypes and allergic responses to diisocyanate exposure. Pharmacogenetics 2001, 11(5):437-445.

37. Mapp CE, Fryer AA, De Marzo N, Pozzato V, Padoan M, Boschetto P, Strange RC, Hemmingsen A, Spiteri MA: Glutathione S-transferase GSTP1 is a susceptibility gene for occupational asthma induced by isocyanates. The Journal of allergy and clinical immunology 2002, 109(5):867-872.

38. Demchuk E, Yucesoy B, Johnson VJ, Andrew M, Weston A, Germolec DR, De Rosa CT, Luster MI: A statistical model for assessing genetic susceptibility as a risk factor in multifactorial diseases: lessons from occupational asthma. Environmental health perspectives 2007, 115(2):231-234

39. Gautrin D, Ghezzo H, Infante-Rivard C, Malo JL: Host determinants for the development of allergy in apprentices exposed to laboratory animals. Eur Respir J 2002, 19(1):96-103.

40. Nieuwenhuijsen MJ, Putcha V, Gordon S, Heederik D, Venables KM Cullinan P, Newman-Taylor AJ: Exposure-response relations among laboratory animal workers exposed to rats. Occupational and environmental medicine 2003, 60(2):104-108.

41. Malo JL, Lemiere C, Desjardins A, Cartier A: Prevalence and intensity of rhinoconjunctivitis in subjects with occupational asthma. Eur Respir $\rfloor$ 1997, 10(7):1513-1515.

42. Asher MI, Montefort S, Bjorksten B, Lai CK, Strachan DP, Weiland SK, Williams $\mathrm{H}$ : Worldwide time trends in the prevalence of symptoms of asthma, allergic rhinoconjunctivitis, and eczema in childhood: ISAAC Phases One and Three repeat multicountry cross-sectional surveys. Lancet 2006, 368(9537):733-743.

43. McKeever TM, Britton J: Diet and asthma. American journal of respiratory and critical care medicine 2004, 170(7):725-729.

44. Okoko BJ, Burney PG, Newson RB, Potts JF, Shaheen SO: Childhood asthma and fruit consumption. Eur Respir J 2007, 29(6):1161-1168.

45. Shaheen SO, Sterne JA, Thompson RL, Songhurst CE, Margetts BM, Burney PG: Dietary antioxidants and asthma in adults: population-based casecontrol study. American journal of respiratory and critical care medicine 2001, 164(10 Pt 1):1823-1828.

46. Romieu I, Trenga C: Diet and obstructive lung diseases. Epidemiologic reviews 2001, 23(2):268-287.

47. Gueant JL, Anello G, Bosco P, Gueant-Rodriguez RM, Romano A, Barone C, Gerard P, Romano C: Homocysteine and related genetic polymorphisms in Down's syndrome IQ. Journal of neurology, neurosurgery, and psychiatry 2005, 76(5):706-709.

48. Gueant-Rodriguez RM, Juilliere Y, Nippert M, Abdelmouttaleb I, Herbeth B, Aliot E, Danchin N, Gueant JL: Left ventricular systolic dysfunction is an independent predictor of homocysteine in angiographically documented patients with or without coronary artery lesions. J Thromb Haemost 2007, 5(6):1209-1216

49. Husemoen LL, Toft U, Fenger M, Jorgensen T, Johansen N, Linneberg A: The association between atopy and factors influencing folate metabolism: is low folate status causally related to the development of atopy? International journal of epidemiology 2006, 35(4):954-961.

50. Mounier-Geyssant E, Barthelemy JF, Mouchot L, Paris C, Zmirou-Navier D: Exposure of bakery and pastry apprentices to airborne flour dust using PM2.5 and PM10 personal samplers. BMC public health 2007, 7:311.

51. Mounier-Geyssant E, Oury V, Mouchot L, Paris C, Zmirou-Navier D: Exposure of hairdressing apprentices to airborne hazardous substances. Environ Health 2006, 5:23.

52. Tossa P, Bohadana A, Demange V, Wild P, Michaely JP, Hannhart B, Paris C, Zmirou-Navier D: Early markers of airways inflammation and occupational asthma: rationale, study design and follow-up rates among bakery, pastry and hairdressing apprentices. BMC public health 2009, 9:113.

53. Standardization of Spirometry, 1994 Update. American Thoracic Society. American journal of respiratory and critical care medicine 1995, 152(3):1107-1136.

54. Global Initiative for Asthma. Global strategy for asthma management and prevention. Updated 2009 [http://www.ginasthma.com/

55. Pellegrino R, Viegi G, Brusasco V, Crapo RO, Burgos F, Casaburi R, Coates A, Grinten CPM van der, Gustafsson P, Hankinson J, Jensen R, Johnson DC, MacIntyre N, McKay R, Miller MR, Navajas D, Pedersen OF, Wanger J: Interpretative strategies for lung function tests. Eur Respir $J 2005$, 26(5):948-968

56. Cote J, Kennedy S, Chan-Yeung M: Quantitative versus qualitative analysis of peak expiratory flow in occupational asthma. Thorax 1993, 48(1):48-51

57. Calder $\mathrm{PC}: \mathrm{n}-\mathbf{3}$ polyunsaturated fatty acids, inflammation, and inflammatory diseases. The American journal of clinical nutrition 2006 , 83(6 Suppl):1505S-1519S.

58. Bollander-Gouaille C: Focus on Homocysteine and the Vitamins involved in its metabolism 2nd edition. Paris: Spinger-Verlag; 2002.

59. Moffatt MF, Cookson WO: Tumour necrosis factor haplotypes and asthma. Human molecular genetics 1997, 6(4):551-554.

60. Bidwell J, Keen L, Gallagher G, Kimberly R, Huizinga T, McDermott MF, Oksenberg J, McNicholl J, Pociot F, Hardt C, D'Alfonso S: Cytokine gene polymorphism in human disease: on-line databases. Genes and immunity 1999, 1(1):3-19.

61. Velden PA van den, Reitsma PH: Amino acid dimorphism in IL1A is detectable by PCR amplification. Human molecular genetics 1993, 2(10):1753.

62. Anees W, Gannon PF, Huggins V, Pantin CF, Burge PS: Effect of peak expiratory flow data quantity on diagnostic sensitivity and specificity in occupational asthma. Eur Respir J 2004, 23(5):730-734.

63. Perrin B, Lagier F, L'Archeveque J, Cartier A, Boulet LP, Cote J, Malo JL: Occupational asthma: validity of monitoring of peak expiratory flow rates and non-allergic bronchial responsiveness as compared to specific inhalation challenge. Eur Respir J 1992, 5(1):40-48.

64. Tarlo SM, Liss GM: Occupational asthma: an approach to diagnosis and management. Cmaj 2003, 168(7):867-871

65. Burge PS, Pantin CF, Newton DT, Gannon PF, Bright P, Belcher J, McCoach J, Baldwin DR, Burge CB: Development of an expert system for the interpretation of serial peak expiratory flow measurements in the diagnosis of occupational asthma. Midlands Thoracic Society Research Group. Occupational and environmental medicine 1999, 56(11):758-764.

66. Jacobs JH, Meijster T, Meijer E, Suarthana E, Heederik D: Wheat allergen exposure and the prevalence of work-related sensitization and allergy in bakery workers. Allergy 2008, 63(12):1597-1604.

67. Gautrin D, Ghezzo H, Infante-Rivard C, Magnan M, L'Archeveque J, Suarthana $E$, Malo JL: Long-term outcomes in a prospective cohort of apprentices exposed to high-molecular-weight agents. American journal of respiratory and critical care medicine 2008, 177(8):871-879.

68. Gautrin D, Ghezzo H, Infante-Rivard C, Malo JL: Incidence and determinants of IgE-mediated sensitization in apprentices. A prospective study. American journal of respiratory and critical care medicine 2000, 162(4 Pt 1):1222-1228.

69. Houba R, Heederik DJ, Doekes G, van Run PE: Exposure-sensitization relationship for alpha-amylase allergens in the baking industry. 
American journal of respiratory and critical care medicine 1996, 154(1):130-136

70. Tiikkainen U, Louhelainen K, Nordman H: Flour dust. In The Nordic Expert Group for Criteria Documentation of Health Risks fiom Chemicals Nordic Council of Ministers. Arbete och Halsa; 1996:27.

71. Akpinar-Elci M, Cimrin AH, Elci OC: Prevalence and risk factors of occupational asthma among hairdressers in Turkey. Journal of occupational and environmental medicine/American College of Occupational and Environmental Medicine 2002, 44(6):585-590.

72. I watsubo Y, Matrat M, Brochard P, Ameille J, Choudat D, Conso F, Coulondre D, Garnier R, Hubert C, Lauzier F, Romano MC, Pairon JC: Healthy worker effect and changes in respiratory symptoms and lung function in hairdressing apprentices. Occupational and environmental medicine 2003, 60(11):831-840.

73. Devereux G, Seaton A: Diet as a risk factor for atopy and asthma. The Journal of allergy and clinical immunology 2005, 115(6):1109-1117.

74. Mickleborough TD, Lindley MR, lonescu AA, Fly AD: Protective effect of fish oil supplementation on exercise-induced bronchoconstriction in asthma. Chest 2006, 129(1):39-49.

75. Patel BD, Welch AA, Bingham SA, Luben RN, Day NE, Khaw KT, Lomas DA Wareham NJ: Dietary antioxidants and asthma in adults. Thorax 2006, 61(5):388-393.

76. Gilliland FD, Berhane KT, Li YF, Gauderman WJ, McConnell R, Peters J: Children's lung function and antioxidant vitamin, fruit, juice, and vegetable intake. American journal of epidemiology 2003, 158(6):576-584

77. Hu G, Cassano PA: Antioxidant nutrients and pulmonary function: the Third National Health and Nutrition Examination Survey (NHANES III). American journal of epidemiology 2000, 151(10):975-981.

78. Butland BK, Fehily AM, Elwood PC: Diet, lung function, and lung function decline in a cohort of 2512 middle aged men. Thorax 2000 55(2):102-108.

79. Schunemann HJ, Grant BJ, Freudenheim JL, Muti P, Browne RW, Drake JA, Klocke RA, Trevisan M: The relation of serum levels of antioxidant vitamins $C$ and $E$, retinol and carotenoids with pulmonary function in the general population. American journal of respiratory and critical care medicine 2001, 163(5):1246-1255.

80. Fogarty A, Lewis S, Weiss S, Britton J: Dietary vitamin E, lgE concentrations, and atopy. Lancet 2000, 356(9241):1573-1574

81. Hijazi N, Abalkhail B, Seaton A: Diet and childhood asthma in a society in transition: a study in urban and rural Saudi Arabia. Thorax 2000, 55(9):775-779

82. Schneider AP, Stein RT, Fritscher CC: The role of breastfeeding, diet and nutritional status in the development of asthma and atopy. J Bras Pneumol 2007, 33(4):454-462.

83. Mapp CE: What is the role of genetics in occupational asthma? Eur Respir J 2009, 33(3):459-460.

84. Levy ML, Fletcher M, Price DB, Hausen T, Halbert RJ, Yawn BP: International Primary Care Respiratory Group (IPCRG) Guidelines: diagnosis of respiratory diseases in primary care. Prim Care Respir J 2006, 15(1):20-34

85. Malo JL, Ghezzo H, L'Archeveque J, Lagier F, Perrin B, Cartier A: Is the clinical history a satisfactory means of diagnosing occupational asthma? The American review of respiratory disease 1991, 143(3):528-532.

86. Tarlo SM, Balmes J, Balkissoon R, Beach J, Beckett W, Bernstein D, Blanc PD, Brooks SM, Cowl CT, Daroowalla F, Harber P, Lemiere C, Liss GM, Pacheco KA, Redlich CA, Rowe B, Heitzer J: Diagnosis and management of workrelated asthma: American College Of Chest Physicians Consensus Statement. Chest 2008, 134(3 Suppl):1S-41S

87. Hetzel MR, Clark TJ: Comparison of normal and asthmatic circadian rhythms in peak expiratory flow rate. Thorax 1980, 35(10):732-738

88. Hayati F, Maghsoodloo S, DeVivo MJ, Thomas RE, Lemiere C: Quality control chart method for analyzing PEF variability in occupational asthma. American journal of industrial medicine 2008, 51(3):223-228.

89. Henneberger PK, Stanbury MJ, Trimbath LS, Kipen HM: The use of portable peak flowmeters in the surveillance of occupational asthma. Chest 1991, 100(6):1515-1521.

90. Tarlo SM, Broder I: Outcome of assessments for occupational asthma. Chest 1991, 100(2):329-335.

91. Moscato G, Pignatti P, Yacoub MR, Romano C, Spezia S, Perfetti L: Occupational asthma and occupational rhinitis in hairdressers. Chest 2005, 128(5):3590-3598
Pre-publication history

The pre-publication history for this paper can be accessed here: http://www.biomedcentral.com/1471-2458/10/206/prepub

doi: 10.1186/1471-2458-10-206

Cite this article as: Rémen et al., Early incidence of occupational asthma among young bakers, pastry-makers and hairdressers: design of a retrospective cohort study BMC Public Health 2010, 10:206

\section{Submit your next manuscript to BioMed Centra and take full advantage of:}

- Convenient online submission

- Thorough peer review

- No space constraints or color figure charges

- Immediate publication on acceptance

- Inclusion in PubMed, CAS, Scopus and Google Scholar

- Research which is freely available for redistribution

Submit your manuscript at www.biomedcentral.com/submit
C) Biomed Central 